\title{
Pengaruh ekstrak kulit buah manggis Garcinia mangostana L.) terhadap kualitas spermatozoa tikus wistar (Rattus norvegicus) yang dipapari asap rokok
}

\author{
${ }^{1}$ Milary Wuisan \\ ${ }^{2}$ Lydia Tendean \\ ${ }^{2}$ Janette M. Rumbajan
}

\author{
${ }^{1}$ Kandidat Skripsi Fakultas Kedokteran Universitas Sam Ratulangi Manado \\ ${ }^{2}$ Bagian Biologi Fakultas Kedokteran Universitas Sam Ratulangi Manado \\ Email: milarywuisan12053@gmail.com
}

\begin{abstract}
Cigarette smoke causes oxidative stress which impact on the quality of spermatozoa. Xanthones in mangosteen rind extract acts as an antioxidant to neutralize free radicals as resistance to oxidative stress. This study aimed to determine the effect of mangosteen rind extract to the quality of spermatozoa of wistar rats that are exposed to cigarette smoke. This research is an experimental approach to post-test only control group design. Samples were 9 wistar rats divided 3 groups: The control group was given exposure to cigarette smoke 1 cigarettes/day, treatment group 1 was given exposure to cigarette smoke 1 cigarettes/day and extract mangosteen rind $10 \mathrm{mg} / \mathrm{kg} /$ day, treatment group 21 given exposure to cigarette smoke cigarettes/day and mangosteen peel extract $20 \mathrm{mg} / \mathrm{kg} / \mathrm{day}$. The treatment was done for 50 days. The result showed that treatment 1 and treatment 2 shows the improvement of the quality of spermatozoa with an average concentration $(85.7 \times 105 / \mathrm{ml}$ and $76.6 \times 105 / \mathrm{ml}$ ), average percentage of normal motility $(76.76 \%$ and $85 \%)$, and average percentage of normal morphology (90\% and 98.67\%). Conclusion: mangosteen rind extract can improve the quality of spermatozoa (concentration and motility) of wistar rats (Rattus norvegicus) that are exposed to cigarette smoke.
\end{abstract}

Keywords: quality of spermatozoa, xanthones, smoke, oxidative stress

\begin{abstract}
Abstrak: Asap rokok menyebabkan stres oksidatif yang berdampak pada penurunan kualitas spermatozoa. Xanthone dalam ekstrak kulit buah manggis sebagai antioksidan berperan menetralisir radikal bebas sebagai perlawanan terhadap stres oksidatif. Penelitian ini bertujuan untuk mengetahui pengaruh pemberian ekstrak kulit buah manggis terhadap kualitas spermatozoa tikus wistar yang dipapari asap rokok. Penelitian ini merupakan penelitian eksperimental dengan pendekatan post-test only control group design. Subyek penelitian sebanyak 9 ekor wistar yang dibagi menjadi 3 kelompok: Kelompok kontrol diberikan paparan asap rokok 1 batang/hari, kelompok perlakuan 1 diberikan paparan asap rokok 1 batang/hari dan ektrak kulit buah manggis $10 \mathrm{mg} / \mathrm{kgBB} /$ hari, kelompok perlakuan 2 diberikan paparan asap rokok 1 batang/hari dan ektrak kulit buah manggis $20 \mathrm{mg} / \mathrm{kgBB} / \mathrm{hari}$. Perlakuan dilakukan selama 50 hari. Hasil penelitian pada perlakuan 1 dan perlakuan 2 menunjukkan perbaikan kualitas spermatozoa dengan rerata konsentrasi $\left(85,7 \times 10^{5} / \mathrm{ml}\right.$ dan $\left.76,6 \times 10^{5} / \mathrm{ml}\right)$, rerata motilitas normal (76,76\% dan 85\%), rerata morfologi normal (90\% dan 98,67\%). Simpulan: Pemberian ekstrak kulit buah manggis dapat meningkatkan kualitas spermatozoa (konsentrasi dan motilitas) dari tikus wistar (Rattus norvegicus) yang dipapari asap rokok.
\end{abstract}

Kata kunci: kualitas spermatozoa, xanthone, asap rokok, stres oksidatif

Pada tahun 2007 Indonesia menempati posisi kelima di dunia dalam jumlah 
konsumsi rokok dengan jumlah 215 miliar batang. Berdasarkan Survei Kesehatan Rumah Tangga tahun 2004, sekitar 31,4 \% penduduk Indonesia adalah perokok dan sebanyak 59,04 \% perokok adalah lakilaki. ${ }^{1}$

Penelitian Mehrania 2007 menemukan bahwa merokok secara signifikan menurunkan kualitas cairan ejakulat berupa penurunan $\mathrm{pH}$, penurunan volume semen, jumlah, dan viabilitas spermatozoa. ${ }^{2}$

Rokok menyebabkan stres oksidatif dengan meningkatkan pembentukan Reactive Oxygen Species (ROS) dan menurunkan level antioksidan endogen testis, yang berakibat gangguan pada siklus pembentukan sperma sehingga berdampak pada penurunan kualitas sperma. ${ }^{1}$ Stres oksidatif merupakan suatu kondisi ketidakseimbangan antara produksi radikal bebas atau ROS dengan antioksidan, dimana kadar radikal bebas lebih tinggi dibandingkan antioksidan. ${ }^{3}$ Antioksidan merupakan salah satu perlawanan terhadap stres oksidatif. Beberapa penelitian menunjukan bahwa intervensi dalam diet, berupa pemberian antioksidan berpotensi untuk memperbaiki gangguan reproduksi pria oleh stres oksidatif. ${ }^{1}$

Kulit buah manggis sebagai antioksidan alami mengandung senyawa xanthone, mangostin, garsinon, flavonoid, dan tannin. ${ }^{4}$ Xanthone adalah sejenis senyawa organik dalam senyawa fenol yang ditemukan dalam konsentrasi sangat tinggi di dalam kulit Manggis (Garcinia mangostana L.). ${ }^{5}$ Ekstrak kulit manggis (Garcinia mangostana L.) meningkatkan motilitas dan jumlah spermatozoa mencit Swiss-Webster yang diinduksi latihan fisik berat. $^{6}$

Salah satu fungsi dari ekstrak kulit manggis adalah sebagai antioksidan yang mampu meredam radikal bebas. ${ }^{3}$ Berdasarkan hal tersebut, peneliti ingin mengetahui pengaruh ekstrak kulit buah manggis (Garcinia mangostana L.) terhadap kualitas spermatozoa tikus wistar (Rattus norvegicus) yang dipapari asap rokok.

\section{METODE PENELITIAN}

Penelitian ini merupakan penelitian eksperimental dengan pendekatan post-test only control group design. Penelitian dilakukan di Laboratorium Biologi Fakultas Kedokteran Universitas Sam Ratulangi Manado dengan rentang waktu sekitar Oktober-Desember 2015. Sampel yang digunakan yaitu tikus wistar (Rattus norvegicus) berumur 12 - 15 bulan dengan berat 200 - 250 gram.

Sampel berjumlah 9 ekor tikus wistar jantan dan dibagi menjadi 3 kelompok, masing-masing terdiri dari 3 ekor tikus wistar. Kelompok kontrol dilakukan pemaparan asap rokok 1 batang/hari; kelompok perlakuan 1 dilakukan pemaparan asap rokok 1 batang/hari dan diberi ekstrak kulit buah manggis $10 \mathrm{mg}$; kelompok perlakuan 2 dilakukan pemaparan asap rokok 1 batang/hari dan diberi ekstrak kulit buah manggis $20 \mathrm{mg}$. Penelitian dilakukan selama 50 hari. Data penelitian ini dianalisis menggunakan program SPSS for window versi 20 yang meliputi analisis deskriptif, analisis normalitas dengan One-Sample Kolmogorov-Smirnov Test, analisis homogenitas dengan Levene's test, dan analisis komparabilitas menggunakan uji $t-$ independent.

\section{HASIL PENELITIAN \\ Konsentrasi spermatozoa}

Setelah dilakukan perlakuan paparan asap rokok dan pemberian ekstrak kulit buah manggis selama 50 hari dan penelitian terhadap konsentrasi spermatozoa tikus wistar (Rattus norvegicus) pada masingmasing kelompok maka didapatkan kecenderungan penurunan konsentrasi spermatozoa pada kelompok kontrol sedangkan pada kelompok perlakuan 1 dan perlakuan 2 cenderung mengalami peningkatan (Tabel 1).

Berdasarkan uji komparabilitas menggunakan uji t-independent untuk membandingkan rerata konsentrasi spermatozoa antar kelompok didapatkan hasil konsentrasi spermatozoa kelompok perlakuan 1 terhadap kelompok kontrol 
menunjukkan ada perbedaan signifikan dengan nilai $\mathrm{p}=0,036(\mathrm{p}<0,05)$, konsentrasi spermatozoa kelompok perlakuan 2 terhadap kelompok kontrol menunjukkan tidak ada perbedaan signifikan dengan nilai $\mathrm{p}=0,053 \quad(\mathrm{p}>0,05), \quad$ dan konsentrasi spermatozoa kelompok perlakuan 2 terhadap kelompok perlakuan 1 menunjukkan tidak ada perbedaan signifikan dengan nilai $\mathrm{p}=0,415$ ( $\mathrm{p}>0,05)$.

Tabel 1. Rerata konsentrasi spermatozoa kelompok kontrol dan kelompok perlakuan.

\begin{tabular}{cc}
\hline Kelompok & $\begin{array}{c}\text { Rerata konsentrasi } \\
\text { spermatozoa } \\
\left(\times 10^{5} / \mathrm{ml}\right)\end{array}$ \\
\hline Kontrol & 35,68 \\
Perlakuan 1 & 85,7 \\
Perlakuan 2 & 76,6 \\
\hline
\end{tabular}

\section{Motilitas spermatozoa normal}

Motilitas normal adalah motilitas spermatozoa kategori a+b. Kecenderungan penurunan presentase motilitas normal spermatozoa terlihat pada kelompok kontrol dan peningkatan presentase motilitas normal spermatozoa terlihat pada kelompok perlakuan 1 dan perlakuan 2 (Tabel 2).

Tabel 2. Rerata motilitas normal spermatozoa kelompok kontrol dan kelompok perlakuan.

\begin{tabular}{cc}
\hline Kelompok & $\begin{array}{c}\text { Rerata motilitas normal } \\
\text { spermatozoa } \\
(\%)\end{array}$ \\
\hline Kontrol & 6,67 \\
Perlakuan 1 & 76,76 \\
Perlakuan 2 & 85 \\
\hline
\end{tabular}

\section{Motilitas spermatozoa abnormal}

Motilitas abnormal adalah motilitas spermatozoa kategori $\mathrm{c}+\mathrm{d}$. Kecenderungan peningkatan presentase motilitas abnormal spermatozoa terlihat pada kelompok kontrol dan penurunan presentase motilitas abnormal spermatozoa terlihat pada kelompok perlakuan 1 dan perlakuan 2 (Tabel 3).
Tabel 3. Rerata motilitas abnormal spermatozoa kelompok kontrol dan kelompok perlakuan.

\begin{tabular}{cc}
\hline Kelompok & $\begin{array}{c}\text { Rerata motilitas } \\
\text { abnormal spermatozoa } \\
(\%)\end{array}$ \\
\hline Kontrol & 93,33 \\
Perlakuan 1 & 23,33 \\
Perlakuan 2 & 15 \\
\hline
\end{tabular}

Berdasarkan uji komparabilitas menggunakan uji t-independent untuk membandingkan rerata motilitas spermatozoa antar kelompok didapatkan hasil sebagai berikut motilitas spermatozoa kelompok perlakuan 1 terhadap kelompok kontrol menunjukkan ada perbedaan signifikan dengan nilai $\mathrm{p}=0,001(\mathrm{p}<0,05)$, motilitas spermatozoa kelompok perlakuan 2 terhadap kelompok kontrol menunjukkan ada perbedaan signifikan dengan nilai $\mathrm{p}=0,000 \quad(\mathrm{p}<0,05)$, motilitas spermatozoa kelompok perlakuan 2 terhadap kelompok perlakuan 1 menunjukkan tidak ada perbedaan signifikan dengan nilai $\mathrm{p}=0,132$ $(\mathrm{p}>0,05)$.

\section{Morfologi spermatozoa normal}

Rerata morfologi normal spermatozoa kelompok kontrol dan kelompok perlakuan 1 dan perlakuan 2 tidak menunjukkan adanya penurunan yang bermakna (Tabel 4).

Tabel 4. Rerata morfologi normal spermatozoa kelompok kontrol dan kelompok perlakuan.

\begin{tabular}{cc}
\hline Kelompok & $\begin{array}{c}\text { Rerata morfologi } \\
\text { normal spermatozoa } \\
(\%)\end{array}$ \\
\hline Kontrol & 73,33 \\
Perlakuan 1 & 90 \\
Perlakuan 2 & 98,67 \\
\hline
\end{tabular}

\section{Morfologi spermatozoa abnormal}

Rerata morfologi abnormal spermatozoa kelompok kontrol dan kelompok perlakuan 1 dan perlakuan 2 tidak menunjukkan adanya penurunan yang bermakna (Tabel 5). 
Tabel 5. Rerata morfologi abnormal spermatozoa kelompok kontrol dan kelompok perlakuan.

\begin{tabular}{cc}
\hline & $\begin{array}{c}\text { Rerata morfologi } \\
\text { abnormal } \\
\text { spermatozoa } \\
(\%)\end{array}$ \\
\hline Kelompok & 26,67 \\
Perlakuan 1 & 10 \\
Perlakuan 2 & 1,33 \\
\hline
\end{tabular}

Berdasarkan uji komparabilitas menggunakan uji t-independent untuk membandingkan rerata morfologi spermatozoa antar kelompok didapatkan hasil morfologi spermatozoa kelompok perlakuan 1 terhadap kelompok kontrol menunjukkan tidak ada perbedaan signifikan dengan nilai $p=0,226(p>0,05)$, morfologi spermatozoa kelompok perlakuan 2 terhadap kelompok kontrol menunjukkan tidak ada perbedaan signifikan dengan nilai $\mathrm{p}=0,053(\mathrm{p}>0,05)$, morfologi spermatozoa kelompok perlakuan 2 terhadap kelompok perlakuan 1 menunjukkan tidak ada perbedaan signifikan dengan nilai $\mathrm{p}=0,284(\mathrm{p}>0,05)$.

\section{BAHASAN}

Berdasarkan hasil penelitian dan analisis data menunjukkan rerata kualitas spermatozoa kelompok kontrol yaitu kelompok yang dipapari asap rokok sebanyak 1 batang/hari cenderung mengalami penurunan baik dari konsentrasi, motilitas, dan morfologi spermatozoa. Penurunan kualitas spermatozoa ini disebabkan oleh kandungan zat kimia pada asap rokok seperti nikotin, tar, dan karbon monoksida sehingga berpotensi menimbulkan peningkatan radikal bebas. ${ }^{7}$ Asap rokok yang dipaparkan pada tikus menyebabkan stres oksidatif dengan meningkatkan pembentukan ROS dan menurunkan level antioksidan endogen testis, berakibat gangguan pada siklus pembentukan sperma sehingga berdampak pada penurunan kualitas sperma. ${ }^{1}$
Penurunan konsentrasi dan morfologi normal spermatozoa pada kelompok kontrol disebabkan oleh peningkatan radikal bebas karena asap rokok yang merusak membran dari sel-sel spermatogenik, mengganggu transport ionion penting bagi proliferasi dan pertumbuhan sel-sel spermatogenik, merusak DNA spermatozoa, meningkatkan terjadinya apoptosis, dan perubahan morfologi spermatozoa saat spermatogenesis. ${ }^{7,8}$ Penurunan motilitas normal spermatozoa dikarenakan senyawa radikal bebas yang terkandung dalam asap rokok meningkatkan jumlah lipid peroksidasi dan menimbulkan kerusakan serta penurunan integritas membran spermatozoa sehingga mengurangi motilitas. $^{7}$ Radikal bebas juga dapat menurunkan frekuensi gerakan ekor spermatozoa karena radikal bebas menyebabkan produksi ATP mitokondria rendah. Mitokondria merupakan tempat proses perombakan atau katabolisme untuk menghasilkan energi bagi pergerakan ekor spermatozoa. $^{9}$ Batubara 2013, dalam penelitiannya membuktikan bahwa paparan asap rokok 1 batang rokok kretek selama 30 hari sudah dapat menurunkan kualitas spermatozoa mencit dalam hal ini konsentrasi, motilitas, dan morfologi spermatozoa. $^{10}$

Pada penelitian ini didapatkan kualitas spermatozoa kelompok perlakuan 1 yaitu kelompok yang dipapari asap rokok dan diberikan ekstrak kulit buah manggis 10 mg menunjukkan adanya peningkatan dibandingkan kelompok kontrol yaitu kelompok yang hanya dipapari asap rokok. Kualitas spermatozoa meningkat secara signifikan yaitu konsentrasi dan motilitas spermatozoa sedangkan morfologi -katan signifikan.

Peningkatan konsentrasi dan motilitas spermatozoa pada kelompok perlakuan 1 dikarenakan $\alpha$-mangostin yang merupakan komponen terbesar xanthone dalam ekstrak kulit buah manggis mampu menangkal peroksi nitrit (ONOO_), yaitu radikal bebas yang terbentuk dari asap rokok. ${ }^{11}$ Xanthone juga dapat meningkatkan produksi 
testosteron yang merupakan hormon penting yang terlibat dalam produksi dan pematangan spermatozoa di tubulus seminiferus testis. Xanthone sebagai antioksidan juga dapat memperbaiki komunikasi antar sel dan dapat meningkatkan motilitas spermatozoa walaupun diberi paparan asap rokok. ${ }^{12}$

Pada penelitian ini didapatkan kualitas spermatozoa kelompok perlakuan 2 yaitu kelompok yang dipapari asap rokok dan diberikan ekstrak kulit buah manggis 20 mg menunjukkan adanya peningkatan dibandingkan kelompok kontrol yaitu kelompok yang hanya dipapari asap rokok. Kualitas spermatozoa yang meningkat secara signifikan yaitu motilitas spermatozoa, sedangkan konsentrasi dan morfologi spermatozoa tidak menunjukkan peningkatan signifikan. Hal ini disebabkan karena pengaruh radikal bebas yang diproduksi dari zat kimia pada asap rokok yaitu nikotin,tar, dan karbondioksida tinggi sehingga menghambat proses spermatogenesis melalui penurunan jumlah spermatosit pakiten dan spermatid. ${ }^{10}$ Pemberian dosis antioksidan dapat berpengaruh pada laju oksidasi. Pada konsentrasi tinggi, aktivitas antioksidan sering menjadi prooksidan. ${ }^{6}$ Oleh karena itu xanthone sebagai antioksidan hanya memberikan efek kecil dan tidak meningkatkan konsentrasi dan morfologi spermatozoa tikus yang dipapari asap rokok.

Pada penelitian ini didapatkan kualitas spermatozoa kelompok perlakuan 2 yaitu kelompok yang dipapari asap rokok dan diberikan ekstrak kulit buah manggis 20 mg dan merupakan $2 \times$ lipat dosis optimal yang dianjurkan untuk manusia dibandingkan dengan kelompok perlakuan 1 yaitu kelompok yang dipapari asap rokok dan diberikan ekstrak kulit buah manggis $10 \mathrm{mg}$ (dosis optimal yang dianjurkan untuk manusia) tidak menunjukkan perbedaan signifikan baik dari konsentrasi, motilitas, maupun morfologi spermatozoa. Hal ini menunjukkan bahwa pada penelitian ini dengan penambahan dosis ekstrak kulit buah manggis tidak diikuti oleh peningkatan kualitas spermatozoa tikus wistar walaupun dosis antioksidan yang diberikan dapat berpengaruh pada laju oksidasi.

\section{SIMPULAN}

1. Kualitas spermatozoa tikus wistar (Rattus norvegicus) setelah pemberian ekstrak kulit buah manggis (Garcinia mangostana L.) yang dipapari asap rokok mengalami peningkatan signifikan secara statistik yaitu peningkatan pada konsentrasi ( $\mathrm{p}=$ 0,036) dan motilitas spermatozoa normal $(\mathrm{p}=0,01)$ sedangkan pada morfologi spermatozoa normal cenderung mengalami peningkatan meskipun tidak signifikan secara statistik $(p=0,226)$.

2. Ektrak kulit buah manggis (Garcinia mangostana L.) dengan pemberian dosis berbeda yaitu $10 \mathrm{mg}$ dan $20 \mathrm{mg}$ tidak memberikan efek signifikan secara statistik terhadap kualitas spermatozoa tikus wistar (Rattus norvegicus) yang dipapari asap rokok ( $\mathrm{p}>0,05)$.

\section{SARAN}

1. Perlu dilakuakan penelitian selanjutnya mengenai jenis xanthone yang berpengaruh terhadap peningkatan kualitas spermatozoa.

2. Perlu dilakukan penelitian terhadap jenis-jenis radikal bebas yang menyebabkan penurunan kualitas spermatozoa.

\section{DAFTAR PUSTAKA}

1. Suciati T, Ismono D, Iwan J. Pengaruh Likopen Terhadap Gambaran Tubulus Seminiferus dan Kualitas Sperma Mencit (Mus musculus L) yang Terpapar Asap Rokok [skripsi]. Bandung: Fakultas Kedokteran Universitas Padjajaran, Anatomi dan Biologi; 2010.

2. Mehrania T. The Effect Of Cigarrete Smoking On Semen Quality of Infertile Men. Pak J Med Sci. 2007; 23(1).

3. Arsana IN. Ekstak Kulit Buah Manggis (Garcinia mangostana L.) dan 
Pelatihan Fisik Menurunkan Stres Oksidatif Pada Tikus Wistar (Rattus norvegicus) Selama Aktivitas Fisik Maksimal [disertasi]. Denpasar: Universitas Udayana, Program Doktor Program Studi Ilmu Kedokteran; 2014.

4. Miryanti A, Sapei L, Budiono K, Indra S. Ekstraksi Antioksidan Dari Kulit Buah Manggis (Garcinia mangostana L.). Bandung: Universitas Katolik Parahyangan, Lembaga Penelitian dan Pengabdian Kepada Masyarakat; 2011.

5. Ngatin A, Mentik H. Ekstraksi Kulit Buah Manggis Secara Refluks Dan Sokletasi Menggunakan Pelarut Etanol. In Seminar Nasional Sains dan Teknologi 2014; 2014; Jakarta. p.1.

6. Prawira A, ST, Soeng S. The Effect of Mangosteen Peel Extract on Sperm Motility and Sperm Count of Swiss Webster Mice Induce by Hard Physical Exercise. Journal of Medicine and Health. 2015 February; 1.

7. Karim D. Pengaruh Paparan Asap Rokok Elektrik terhadap Motilitas, Jumlah Sperma dan Kadar MDA Testis Mencit (Mus Musculus) [tesis]. Medan: Universitas Sumatera Utara; 2011.1; p. 60-1.
8. Sukmaningsih A. Penurunan Jumlah Spermatosit Pakiten dan Spermatid Tubulus Seminiferus Testis Mencit (Mus musculus) yang Dipaparkan Asap Rokok. Biologi. 2009.12; p. 312

9. Susmiarsih T. Peran Genetik DNA Mitokondria (mtDNA) pada Motilitas Spermatozoa. Pharma Medika vol. 2. 2010.2; p. 1-7.

10. Batubara IVD, Wantouw B, Tendean L. Pengaruh Paparan Asap Rokok Kretek Terhadap Kualitas Spermatozoa Mencit Jantan (Mus musculus). e-Biomedik vol.1. 2013.1; h. 330-37.

11. Jung HA, Su BN, Keller WJ, Mehta RG, Kinghorn AD. Antioxidant xanthones from the pericarp of Garcinia mangostana (Mangosteen). Jurnal Agriculture Food Chemical vol. 56. 2006. 6; p. 2077-82.

12. Permatasari FR, Marhendra APW, Aulanni'am. Studi Terapi Ekstrak Kulit Buah Manggis (Garcinia Mangostana L.) terhadap Penurunan Kadar Malondialdehyde (MDA) pada Organ Testis dan Jumlah Spermatozoa Tikus (Rattus norvegicus) Hasil Induksi Paparan Asap Rokok. Malang: Program Studi Kedokteran Hewan Universitas Brawijaya, 2014; p. 2-6. 